\title{
Átalakuló pártállam és egyenlőtlen túlfütöttség Kínában a globális válság idején
}

\section{The transforming party state and uneven overheating in China during the global crisis}

\author{
CSANÁDI MÁRIA, GYURIS FERENC
}

\begin{abstract}
CSANÁDI Mária: tudományos tanácsadó, MTA Közgazdaság- és Regionális Tudományi Kutatóközpont, Közgazdaságtudományi Intézet; 1097 Budapest, Tóth Kálmán u. 4.; csanadi.maria@krtk.mta.hu; https://orcid.org/0000-0002-1609-3542

GYURIS Ferenc: egyetemi adjunktus, Eötvös Loránd Tudományegyetem, Regionális Tudományi Tanszék, 1117 Budapest, Pázmány Péter sétány 1/c.; gyurisf@caesar.elte.hu; https://orcid.org/0000-0002-3373-8453
\end{abstract}

\section{KULCSSZAVAK: átalakulás; beruházás; Kína; pártállam; túlfütöttség; válság}

ABSZTRAKT: Ebben a cikkben azt vizsgáljuk, hogy az átalakuló kínai pártállami rendszerben a beruházások dinamikája szempontjából milyen rendszerszerü következményei vannak a külső sokkhatáshoz alkalmazkodó állami beavatkozásnak. Elméleti alapon (még e kutatást megelőzően) megfogalmazott hipotéziseinket - az összehasonlító interaktív pártállami modell (IPS) értelmezési keretére támaszkodva - az 1990-es évek végétől statisztikailag igazoljuk. A beruházások túlfutása a kínai pártállamnak is állandó jellemzője, amelyet a párt, az állam és a gazdaság döntéshozói közötti függőségi és érdekérvényesítési viszonyokból kialakuló pártállami hatalmi háló léte és működése, valamint az abban keletkező szerkezeti motivációk okoznak. A pártállami hatalmi háló elemeinek, kapcsolódási és működési elveinek térben, időben és különböző aggregációs szinteken önhasonló jellege miatt a beruházások túlfutása különböző helyeken és idöszakokban, valamint eltérő léptékekben is kimutatható.

A beruházási kilengések gyakorisága a háló által leképezett hatalmi eloszlás aktuális sajátosságainak függvénye. Megállapítjuk, hogy a pártállami háló sokkhatáshoz történő alkalmazkodása a rendszerszerú magatartások intenzitását, ezzel együtt a gazdasági túlfütöttség mértékét is növeli, utóbbi pedig a háló aktuális szerkezete által leképezett hatalmi viszonyok sajátosságaihoz igazodik. Empirikusan igazoljuk, hogy a decentralizált kínai hatalmi hálóban a lokális hatalom túlzott mértékủ beruházása az országosénál intenzívebb. Eredményeink szerint a túlfütöttség egyenlőtlen térbeli intenzitása az állami beavatkozás térbeli és tulajdonbeli prioritásai szerint alakul; a túlfütöttség mértékének időszakos kilengései és a háló aktivitásának átmeneti növekedései (vagyis a háló zsugorodásának lassulása) összefüggenek; a beruházások kilengéseiben, azok felfutásaiban és lecsengéseiben pedig a különböző tulajdonformájú vállalatok eltérő magatartásformái fedezhetők fel.

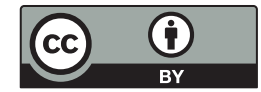


Mária CSANÁDI: research adviser, Institute of Economics, Centre for Economic and Regional Studies, Hungarian Academy of Sciences; Tóth Kálmán u. 4., H-1097 Budapest, Hungary; csanadi.maria@krtk.mta.hu; https://orcid.org/0000-0002-1609-3542

Ferenc GYURIS: assistant professor, Department of Regional Science, Eötvös Loránd University (ELTE); Pázmány Péter sétány 1/c., H-1117 Budapest, Hungary; gyurisf@caesar.elte.hu; https://orcid.org/0000-0002-3373-8453

KEYWORDS: China; crisis; investment; overheating; party state; transformation

ABSTRACT: In this paper, we scrutinize the systemic consequences of state intervention triggered by external shocks in the transforming Chinese economy. Our analysis focuses on the period before and after the global crisis. We regard the analysis of investment dynamics in China as a new opportunity to empirically test the applicability of the system paradigm defined in Csanádi's Interactive Party-State (IPS) model been developed since the 1970s. It describes the power network produced by the institutionalized entanglement of political and economic decisions in communist systems, its individual components, overall structure, the connecting and operating principles and the structural background of the network's different dynamics of operation and transformation.

First, we point out that overinvestment is an outcome of the party-state power consisting of relations of dependency and interest promotion between party, state and economic decision-makers and the emerging structural motivations within the network. The investments fluctuation is the network's internal mechanism to reproduce itself. Second, the model also explains that both the units and the connecting and operating principles of the power network are fractal-like, that is, they are self-similar in space, time and at various levels of aggregation. In consequence, overinvestment occurs at different locations, in different time periods, and at different scales. Both features are general characteristics of communist systems, and thus, of the Chinese party-state.

Besides theoretically deriving both theses from the above model, we also prove them statistically. As we underline, the frequency of investment swings is a function of the power distribution's specificities presented by the party-state network. Overinvestment temporarily increases during external shocks and adapts to the differences of power distribution manifesting in the structure of the network. We present empirically that in the decentralized power network of the Chinese party-state overinvestment by local governments is more intensive than at the national level. We also reveal that the party-state network's adaptation to external shocks intensifies the system-characteristic behavior of the actors and thereby the level of economic overheating. The intensity of economic overheating is uneven in space and corresponds to the regional and ownership type priorities of state intervention. It is the strongest in regions and enterprise ownership types preferred by state intervention. We prove statistically that these features of the Chinese party-state system prevail during economic transformation, and that they also get more intensified during external shocks, for market actors adapt to priorities of resource allocation within the network. We also scrutinize the transformation of the party-state network, that is, its retreat (contraction), both in absolute (compared to previous dates) and relative terms (compared to the sphere outside the network). Here we point out that temporary fluctuations of economic overheating interrelate with the temporary expansions and contractions of the network. We also reveal that the swings of investment, both ups, and downs, hide various patterns of behavior for different enterprise ownership types.

\section{Bevezetés}

A kommunista pártállamok beruházási dinamikája e rendszerek keletkezése óta alapvető problémakörnek számít a tudományos kutatásokban. A „tervszerü, 
arányos fejlődés" sokat hangoztatott ideológiai elvével (Nagy 1954; Sztálin 1953) szemben álló valóságot, a beruházások ciklikus vagy szabálytalan fluktuációját és okait tudományos körökben sem volt egyszerü értelmezni. Széles körű vita alakult ki arról, hogy a tapasztalt fluktuáció valóban ciklikus-e (ismétlődo”, szabályos, előrelátható) vagy sem (Mihályi 1992; Wiles 1982), és hogy a fluktuációt külső vagy belső tényezők okozzák, vagyis az rendszerfüggő-e (Mihályi 1992). A beruházások fluktuációját elemző „korai” tanulmányok az 1960-1980as évekbeli kelet-európai és szovjet pártállami rendszerekkel foglalkoztak, és egyfelől az úgynevezett tervutasításos, másfelől a reformidőszakra fókuszáltak (Bajt 1971; Bauer 1978, 1987; Bródy 1969; Chavance 1987; Goldmann 1965; Ickes 1986; Kornai 1981; Soós 1975, 1986, 1987, 1989; Zou 1993).

Mindkét időszakra a kutatók egyetértettek a túlberuházás létében, valamint annak permanens voltában. Kimondva vagy kimondatlanul a gazdaság túlfütöttségének permanens okát az intézményrendszer sajátos működésében látták: az állami döntéshozás hierarchikus berendezkedésében (Bauer), a paternalista állam preferenciáiban (Kornai), a hiány és a beruházási ciklus dinamikus kölcsönhatásában (Zou), amelyeket közvetlenül a társadalmi tervező optimalizálásra törekvő döntései hoznak létre. Ezen okok véleményük szerint továbbélnek a reformidőszak vegyes intézményi rendszerében is (Soós). A rendszerszerü okok tartósságát részben rendszerszintű jellemzőkre - az állami vállalatok puha költségvetési korlátjára (Kornai) vagy a profitmotiváció hiányára (Soós) - vezették vissza. Az okok között továbbá olyan tényezőket is azonosítottak, mint a folytonos gazdasági növekedés kommunista ideológiából következő türelmetlen hajszolása (Soós, Kornai), illetve olyan rendszerfüggetlen emberi vonásokat, mint általában az intézménnyel való azonosulás, a növekedés és a hatalom vágyának természetes ,állati ösztöne” mind a vállalatvezetők, mind az irányítók részéről (Kornai). A rendszerbeli, ideológiai és emberi sajátosságok mobilizálására szolgáltak a folyamatos aktivizáló kampányok (Soós) a vállalatokkal közvetlen és közvetett kapcsolatban levő társadalmi szervezetek bevonásával. Bajt szerint a kilengések gyakoriságának csökkenését a tervezők idővel halmozódó szabályozási tapasztalatai tették lehetővé. Ehhez hasonló Soós vélekedése, amikor a beruházási ciklusok fennmaradását a reformok inkonzisztenciájának tulajdonítja.

A fenti koncepciók, néhány kivételtől eltekintve (Chavance 1987), nem terjedtek ki az ázsiai pártállami rendszerek beruházási dinamikájának összehasonlító elemzésére. Nem születtek publikációk arról sem, hogy mennyiben hasonlóak vagy eltérőek a kelet-ázsiai pártállami rendszerek átalakulásának beruházási dinamikái, és ezek milyen rendszerbeli okokra vezethetők vissza. ${ }^{1}$ A Kelet-Európához kapcsolódó elméletek, ezen belül Kornai elméletei, azonban jelentős hatással voltak a Kínával foglalkozó nyugati és kínai kutatókra. Az ő elemzéseik a kínai pártállam növekedéséről és beruházásainak „túlfutásáról” - a kínai gazdasági növekedés és átalakulás felgyorsulásával egy időben - az 1990-es évek elejétől születtek. ${ }^{2}$ A nyugati szerzők esetében e tanulmányok a kínai gazdasági fejlődés különböző szakaszait ölelik fel (Ahuja, Nabar 2012; Brandt, Rawski 2008; Chang et al. 2015; Imai 
1994, 1996; Oppers 1997; Zou 1991). Rendszerszerü megközelítéseikben keverednek a piaci szempontú elemek a kelet-európai pártállami rendszerek elemzéséből átvett kategóriákkal. A beruházási ciklusok létét nemcsak a tervutasításos rendszerre (Naughton 1987), hanem a reformidőszakra is kimutatják (Imai 1994, 1996). A beruházások túlfutásának okát a szelektív gazdaságpolitikában, valamint a központi és helyi intézmények ezt követő vagy megerősítő magatartásában és ösztönző eszközeiben látják. Ezek jellemzője az állami tulajdonú vállalatok preferálása a magántulajdonban lévőekkel szemben, a nagyvállalatoké a kicsikkel szemben, a nehéziparé a könnyűiparral szemben, az iparé a mezőgazdasággal szemben, a városi területeké a vidékiekkel szemben, és - a kínai pártállam decentralizált jellegéből fakadóan - a helyi beruházásoké a központiakkal szemben. A szerzők felróják az állami beruházások nagy arányát, a bürokratikus alkumechanizmusok jelenlétét, a gyenge pénzügyi elszámoltathatóság fennmaradását és a bankhitelek költségvetési preferenciákhoz hasonló szelektív odaítélését a piaci koordináció előrehaladása dacára. Mivel azonban az egyes beruházási ciklusok okait sok esetben aktuális piaci és gazdaságpolitikai összetevők szerint értékelik, nem térnek ki arra, hogy ezek a sajátosságok miért maradnak fenn, és nem találnak közös rendszerszerü magyarázatot az ismétlődésekben sem.

A Kínában dolgozó szerzők inkább a túlzott beruházási tevékenység következményeire, a folyamatosan jelen levőnek tekintett túlkapacitásra és alulhasznosításra fókuszálnak. Ezeket a Kínai Népköztársaságban égetően aktuális problémákat - a nyugati elemzőkhöz hasonlóan - összefüggésbe hozzák a túlzott beruházással, a politikai ciklusokkal, a helyi kormányzatok politikailag érzékeny magatartásával (a pozíciók birtoklásának időtartamához kötődő teljesítménykényszerrel és a helyi protekcionizmussal), az olcsó erőforrásokkal, a helyi kormányzati garanciavállalással, továbbá a nagy állami vállalatok preferálásával. Mind az állandónak tekintett túlkapacitás jelenségeinek, mind a megoldásoknak az okait gazdaságpolitikai intézkedésekben látják: a piacosításban, a kormányzati ösztönzők átalakításában, a kereslet növelésében és az erőforrások optimálisabb allokációjában. Összességében mindkét csoport írásaiban megjelennek a rendszerszerü elemek, de sem a kritizált jelenségek, sem a megszüntetésükre javasolt törekvések ismételt kudarcának rendszerspecifikus okait nem vizsgálják.

A továbbiakban e kérdések rendszerbeli hátterére és annak kínai specifikumaira világítunk rá, majd rátérünk a túlberuházás és túlfütöttség fogalmának operacionalizálására és számszerü bemutatására országos, valamint tartományi szinten.

\section{A beruházások „túlfutásának” szerkezeti és dinamikai háttere a pártállamokban}

A kínai beruházások dinamikájának vizsgálatát új lehetőségnek tekintjük a hetvenes évek óta finomított rendszerparadigma (Csanádi 1995, 1997, 2006, 2014, 
2016a; Csanádi, Lai 2003; Csanádi, Lai, Gyuris 2009) empirikus tesztelésére. ${ }^{3}$ Ezt a rendszerparadigmát az interaktív pártállami modell (IPS) képezi le (Csanádi 1995), amely a kommunista rendszerek hatalmi hálójának elemeit, kapcsolódási és működési elveit, szerkezetét, ezek eltéréseit, valamint működésének és átalakulásának eltérő dinamikáját írja le. Az IPS-modell pártállami rendszerként értelmezi a párt, az állam és a gazdaság szereplői közötti intézményesült és informális függőségi és érdekérvényesítési viszonyokból kialakult politikailag monopolizált hatalmi hálót. Ez a háló a pártból kiindulva, annak hatalmi eszközeivel lefedi (integrálja) a párton kívüli döntéseket a pozíciók, a tevékenységek és a szervezeti egységek struktúráján, valamint az egyéni párttagokon keresztül (Csanádi 1997). A modell az előbbiek segítségével megfogalmazza a kommunista rendszerek általános vonásait, amelyek az egyes pártállami rendszerek összehasonlítását közös alapra helyezik. Rámutat továbbá azokra a rendszerspecifikus jellemzőkre, amelyek a pártállami rendszerek különböző változatainak eltérő szerkezetét, valamint változatos müködési és átalakulási dinamikáját értelmezhetővé teszik. A kínai rendszert ezek alapján a pártállami rendszerek egyik átalakulófélben lévő, decentralizált változatának tekintjük, és nem a mainstream irodalomban gyakorta felbukkanó - zömében kapitalista rendszert feltételező - számtalan rendszerparadigma ${ }^{4}$ valamelyikébe soroljuk (Csanádi 2016b).

Az interaktív dinamikus összehasonlító modellünk rendszerparadigmatikus gondolatmenetre, értelmezésre épül, így bizonyos fogalmak használatában hasonlóságot mutat például a Kornai $(1999,2016)$ által definiált rendszerparadigmával. Ugyanakkor alapelveiben, felépítésében és dinamikájában is eltér attól, valamint az ott felvázolt, a bürokratikus és a piaci koordináció koncepciójára (Kornai 1983) építő oksági modelltől (Kornai 1993, 380-385.). Kornai rendszerparadigmájától eltérően ugyanis a hatalmi háló müködését alapvető tényezőnek tekintjük (Csanádi 1997). Ebben a kontextusban értelmezzük a kommunista párt politikai entitásból politikailag monopolizált rendszerré történő fejlődését; a párt, az állam és a gazdaság döntéshozói közötti függőségi és érdekérvényesítési hálót; a pártnak az összes alszférát - így a gazdaságot is - intézményesen integráló funkcióját; a hatalmi háló politikailag monopolizált jellegét, valamint térben, időben és különböző aggregációs szinteken önhasonló tulajdonságait; a politikailag monopolizált háló meghatározó szerepét az erőforráselosztásban és a politikailag racionális gazdasági magatartásban; továbbá a költségvetés puhaságának politikailag racionális, szelektív mivoltát. Kornai rendszerparadigmájának számos fontos megállapítását (pl. puha költségvetési korlát, hiány, a szereplők motivációjának háttere) ugyanakkor felhasználjuk és a pártállami háló müködése szempontjából újraértelmezzük. ${ }^{5}$

Az 1970-es évek óta végzett, összehasonlító empirikus esettanulmányokra épített munkáinkban megállapítottuk, hogy a kommunista pártállamok általános tulajdonságai közé tartozik a szereplők politikailag racionális gazdasági magatartása. Ez egyaránt jelenti az erőforrások szelektíven puha (a hatalmi hálóban erősebben beágyazott szereplőket preferáló) elosztását, valamint az erő- 
forrásokért folyamodás jellegzetességeit (beruházási, készletezési, növekedési, kapcsolatteremtési hajsza). Ez a strukturális magatartás az, amely a költségvetési korlát szelektív puhaságát és a beruházások szelektív túlfutását, az ezek hatására alkalmanként fellépő erőforráshiányt és vele a háló újratermelődési korlátainak keményedését, a pártállami kohézió időszakonkénti gyengülését, valamint az állami beavatkozás alkalmankénti felerősödését is előidézi. Tehát a beruházások túlfutása is a kommunista pártállami rendszerek egyik általános jellemzője. ${ }^{6}$

A beruházások fluktuációját a háló szerkezeti és a benne szereplők magatartásbeli sajátosságaiból következő rendszerdinamika részének tekintjük, és a hatalmi háló újratermelődésének folyamatához, ennek időszakos pulzálásához kötjük. A hálóban az egyes szereplők egyszerre tartanak kézben függőségi szálakat, valamint foglyai maguk is az ilyen szálaknak. Mint a szálakat kézbentartók, egyszerre képesek és kényszerülnek is beavatkozni a politikailag monopolizált háló működésébe hatalmi és alkupozícióik fenntartása érdekében. Mint a függőségi szálak által fogvatartottak, egyszerre kiszolgáltatottak és érdekeltek abban, hogy alkalmazkodjanak a függőségi szálakon közvetített elvárásokhoz alkupozícióik megtartása és erőforrások vonzása érdekében. Képesség és kényszer, kiszolgáltatottság és érdek együttesen hozza létre a szereplők politikailag racionális gazdasági magatartását az alkupozíció fenntartása érdekében. Ez a mechanizmus, illetve strukturális motiváció okozza az állandó késztetést a beavatkozásra és a forrásokért folyamodásra, továbbá biztosítja a pártállami háló kohézióját és újratermelödését.

E kettős pozícióban a szereplők a szálak kézbentartóiként erőforráselvonó és -elosztó képességgel, míg a szálak fogvatartottjaiként erőforrásvonzó, illetve a beavatkozásoknak ellenálló képességgel rendelkeznek. Ezen egymásra is ható képességek együttes mértéke alkotja az adott szereplő alkupozíciójának újratermelési korlátait. A politikailag racionális magatartás mindkét szerepben megjelenik. Érvényesül egyrészt a (költségvetési, banki, központi vagy helyi) erőforráselosztás szelekciós szempontjaiban, ahol a nagy, állami tulajdonban lévő, politikai és állami kapcsolatokat halmozó vállalatok a privilegizáltak. Ennek a politikailag racionális szelekciónak a következtében a szereplők költségvetési korlátja, illetve a hatalmi háló kontextusában kialakult alkupozícióik újratermelési korlátai nem általában puhák (Kornai 1981), hanem szelektíven: a preferált szereplőké „puhább”, mint a többieké. A politikailag racionális gazdasági magatartás ugyanakkor megjelenik a szereplők másik, „,fogvatartotti” szerepében is: a szelekcióhoz való alkalmazkodás érdekében állandósul a készletezés, a beruházási hajsza és a kapcsolatteremtési hajsza - vagyis mindaz, ami az állandó beruházási nyomás strukturális hátterét alkotja, és a beruházások túlfutását előidézi. Ez a strukturális motiváció vezet alkalmanként az egész rendszer újratermelődésének keményedő korlátaihoz - a relatív hiányhoz -, amely a háló kohézióját lazítja, a beruházások fluktuációját előidézi, és ismétlődő beavatkozásra késztet. 
Az IPS-modell értelmezésében a háló által megtestesített hatalmi szerkezet térben, időben és különböző aggregációs szinteken önhasonló. A rá jellemző kapcsolódási és múködési elvek, valamint szerkezeti motivációk - ezek következményeként pedig a beruházások túlfutása és a gazdasági túlfütöttség is - megtalálhatóak bármelyik pártállamban (akár a múlt század harmincas éveiben a Szovjetunióban, akár jelenleg Észak-Koreában), egy országon belül akármelyik tartományban, vagy akármelyik állami vállalat esetében, sőt akár egy nemzetközi integráció (a KGST) szintjén is (Csanádi 2006).

Míg a háló tartósságát és az erőforráskorlátokba ütközés (hiány) ismétlődését az általános, önhasonló szerkezeti sajátosságok okozzák, a túlfutás és az erőforráskorlátba ütközés eltérő gyakorisága a háló hatalmi eloszlásának sajátosságaitól, ezen belül az erőforrások elosztásának és elvonásának szerkezetbeli képességétől függ. Ha a hatalmi háló és vele az erőforráselvonás, illetve az erőforráselosztás képessége a hatalmi szerkezetben centralizált (miként az 1950-es években a legtöbb pártállamban, Romániában 1990-ig, Észak-Koreában pedig jelenleg is), akkor a hatalmi háló újratermelődése ritkán ütközik keményedő korlátokba. Amennyiben az erőforráselosztás és -elvonás képessége a hatalmi szerkezetben relatíve decentralizált, ahogy az Kínában Mao decentralizációs kampányai és az ezeket intézményesen felerősítő, hálón belüli decentralizáló reformok hatására bekövetkezett, ${ }^{7}$ a hatalmi háló újratermelődése gyakrabban ütközik keményedő korlátokba.

A hatalmi háló szerkezetétől nemcsak a korlátokba ütközés gyakorisága, s vele a beruházások fluktuációjának sürüsége függ, hanem az is, hogy a beruházások felgyorsulása melyik aggregációs szinten milyen erősséggel jelentkezik. Centralizált hatalmi szerkezet esetén a beruházások ütemének gyorsulása elsősorban felsőbb aggregációs szinten jelentkezik, míg decentralizáltabb hálóban a beruházások gyorsulása és túlfutása a lokális szinteken is hangsúlyosabbá válik. Ez a szerkezeti sajátosság a hatalmi hálóban nemcsak a hálón belüli decentralizáló reformok, hanem a rendszerátalakulás - vagyis a háló fokozatos visszahúzódása (a háló abszolút zsugorodása) és a hálón kívüli szféra terjeszkedése (a háló relatív zsugorodása) - ellenére is érvényesül.

A beruházások rendszerszerü túlfutása alkalmanként „kilenghet”, ha kívülről sokkhatás éri a rendszert. Megközelítésünk szerint a túlfutás amplitúdója, illetve a gazdasági túlfütöttség mértéke ilyenkor azért növekszik, mert a sokkhatásra a rendszer intenzívebb állami beavatkozással reagál, hogy a hatalmi hálónak a sokkhatás következtében meggyengült kohézióját új erőforrások elosztása révén megerősítse (Csanádi 2014).

Cikkünkben arra keressük a választ, hogyan alakul a beruházás dinamikája egy adott hatalmi eloszlású pártállami szerkezetben a rendszerátalakulás folyamatának adott szakaszában, külső sokkhatás és az arra reagáló központi beavatkozás esetén. Hogyan befolyásolja a beruházás dinamikáját és térbeli jellegzetességeit a szelektív erőforráselosztás, az eltérő tulajdoni hátterű alanyok magatartása, és milyen rendszerdinamikai következményei vannak az ő 
egymásra hatásuknak? Az elméleti bevezetőben megfogalmazott gondolatok érvényességét az átalakulófélben lévő, decentralizált hatalmi szerkezetű kínai pártállami rendszeren fogjuk számszerủen tesztelni.

\section{A túlfutás és a túlfütöttség mértékének gyakorlati mérése}

Az átalakuló kínai hatalmi háló működését és a beruházások fluktuációját olyan időszak részeként vizsgáljuk, amikor három külső sokkhatás is érte a kínai gazdaságot: a kelet-ázsiai válság, a WTO-ba történt belépés és a 2008-ban kibontakozó globális válság. A cikkben a globális válság okozta sokkra fókuszálunk, mivel egyelőre ezt az időszakot vizsgáltuk meg behatóan. Adatbázisunk döntően a Kínai Statisztikai Hivatal országos évkönyveiben (China Statistical Yearbook) közölt országos és tartományi statisztikákra épül. ${ }^{8}$

A beruházások túlfutásának mértékét relatív kategóriaként, valamely más mutató dinamikájához képest értelmezzük. Számszerüsítésére többféle elvi lehetőség kínálkozik. Elméletileg mérhető a túlberuházás következménye: a túlkapacitás, vagyis a tényleges kihasználtságnál nagyobb kapacitás; a túltermelés, tehát a valós eladásokat meghaladó termelés; valamint az eladás és a készletek viszonya. Lehet a túlfutás mértékének közvetlen dinamikus mutatója is, ${ }^{9}$ például a beruházások és a GDP dinamikájának viszonya. Mi ez utóbbit választottuk. (Elviekben a közvetett méréseknek is lenne értelme, de a kínai gazdaság esetében a teljes kapacitásra, valamint a készletre vonatkozó adatok nem állnak rendelkezésre.)

A két mutató közül hol a beruházások, hol a GDP növekedése haladja meg a másikét. Az első esetet nevezzük a beruházások túlfutásának, a különbség pedig a túlfutás amplitúdóját, vagyis a gazdaság túlfütöttségének mértékét jelzi. ${ }^{10} \mathrm{~A}$ második esetet a beruházási aktivitás lassulásaként, a gazdaság hűléseként értelmezzük, a két mutató különbségét pedig a hűlés mértékeként. A beruházások dinamikáját (és így a túlfütöttség mértékét) a hálón belüli és a hálón kívüli vállalatok beruházásainak figyelembevételével számítjuk. Utóbbiak jelentősége az átalakulás előrehaladásával (a háló abszolút és relatív zsugorodásával) megnő.

A háló dinamikáját is megpróbáljuk számszerüsíteni. A háló létének közvetlen jeleként kezeljük azokat a vállalatokat, amelyek a háló szálaihoz pozíció és tevékenység alapján, valamint szervezeti szempontból közvetlenül kötődnek. A Kínai Statisztikai Hivatal tulajdonforma szerint 11 vállalattípust különböztet meg, amelyek közül az állami, a kollektív tulajdonú, a kooperatív és a közös tulajdonú vállalatokat soroljuk ebbe a csoportba, a többit hálón kívülinek tekintjük. Számos vállalati adattáblában ugyanakkor nem közlik mind a 11 típus értékeit, köztük több olyan kategóriáét sem, amelyek erősen kötődnek a pártállami hálóhoz. Az állami vállalatok adatai ugyanakkor minden esetben önállóan 
1. ábra: Az állóeszköz-beruházások százalékos megoszlása vállalati tulajdonformák szerint Kínában (2006-2015)

The distribution of investment in fixed assets by enterprise ownership types in China (2006-2015)

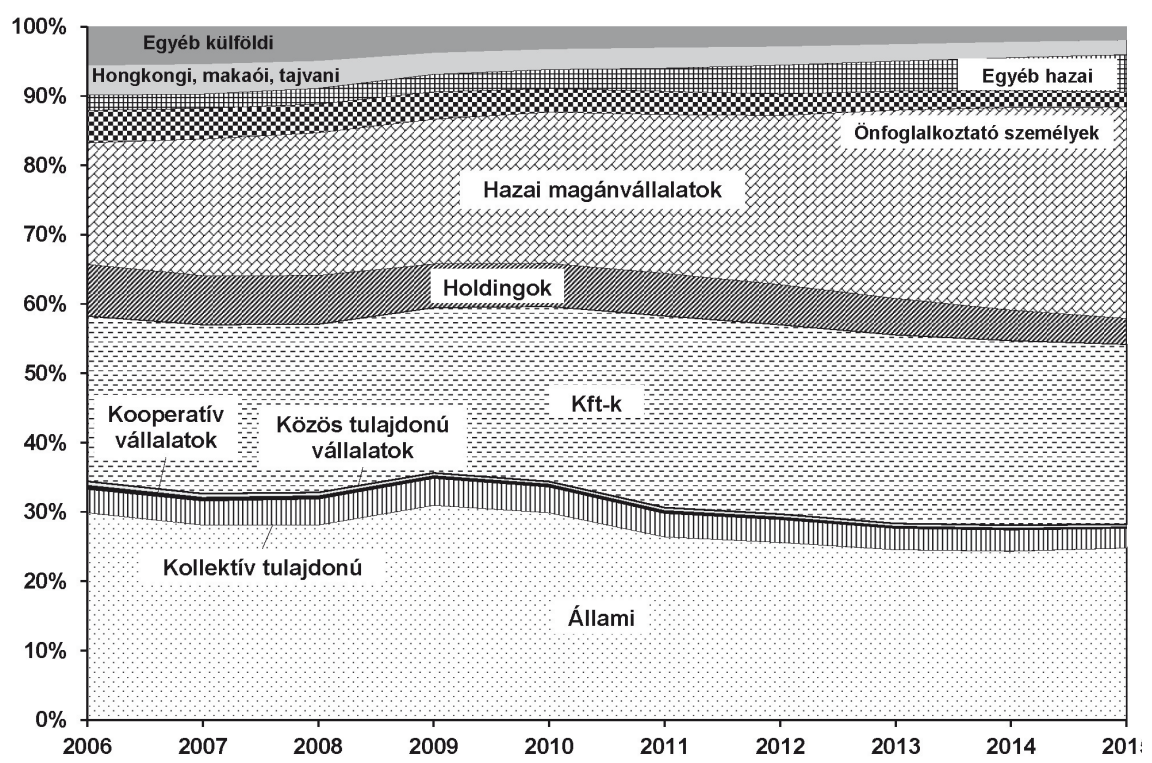

Adatok forrása: CSY (2016).

szerepelnek. Ráadásul a hálón belül a beruházások döntő többsége az állami vállalatokhoz kötődik (1. ábra). A számításainkban ezért az állami beruházások adatait elemezzük, amelyeket a háló létének robusztus indikátoraiként is értelmezünk. Ezek változása markánsan utalhat a háló dinamikájára, időszakos kiterjedésére és visszahúzódására a hálón belüli szereplők aktivitásának hatására.

A gazdaság másik jelentős szegmensében azok a vállalatok találhatók, amelyek a háló befolyásától kevésbé vagy intézményesen nem függenek. Ezt tekintjük a hálón kívüli szférának: a hazai magánvállalatokat, a kft.-ket, a holdingokat, a külföldi vállalatokat (amelyen belül a statisztika megkülönbözteti egyrészről a hongkongi, makaói, tajvani gyökerü, másrészről az egyéb illetőségű külföldi vállalatokat, vegyesvállalatokat), az önfoglalkoztató személyeket, valamint az egyéb, összességében rendkívül szerény súlyú nem állami vállalatokat. Elemzésünkben a hálón kívüli és azon belüli vállalatok beruházási ütemének egymáshoz viszonyított változása jelzi a háló aktuális összehúzódását vagy kiterjedését, s vele a gazdasági alszféra átalakulásának változó dinamikáját. 


\section{Vizsgálati eredmények}

Első lépésben a beruházások túlfutásának (a gazdaság túlfütöttségének) mérésére törekedtünk. Ennek érdekében az állóeszköz-beruházások és a bruttó hazai termék éves növekedésének alakulását vetettük össze az 1997-től 2015-ig tartó időszakban, amelynek során a már említett három külső „sokkhatás” érte a kínai gazdaságot: az ázsiai válság (1997-1999), a WTO-ba való belépés (2002) és a globális válság (2008-2010). Mindegyik esemény rendkívül erős állami beavatkozást váltott ki (Wong 2011; Yuan 2015). Ebben az időszakban a központi és a helyi költségvetési kiadások, valamint a beruházási célú hitelek kihelyezése egyaránt gyors növekedésnek indult. Erőteljes beruházásélénkítő intézkedéseket hoztak, amelyek jelentős külföldi tőkebeáramláshoz, valamint a pénzügyi tartalékok erőteljes igénybevételéhez vezettek. Mindez 1998-ban, 2003-ban és 2009-ben a beruházások hirtelen növekedésével járt együtt, mégpedig úgy, hogy a GDP-növekedés üteme eközben nem nőtt jelentősen (sőt 1998-ban és 2009-ben csökkent) (2. ábra), tehát túlfütöttség alakult ki. ${ }^{11}$

2. ábra: A GDP és az állóeszköz-beruházások évenkénti változása Kínában reálértéken, valamint a gazdasági túlfütöttség mértéke (a beruházások és a GDP éves növekedésének különbsége) százalékpontban (1997-2015)

Annual change of GDP and investment in fixed assets at constant prices and the intensity of economic overheating (the difference between annual growth rates of investment and GDP) in China in percentage points (1997-2015)

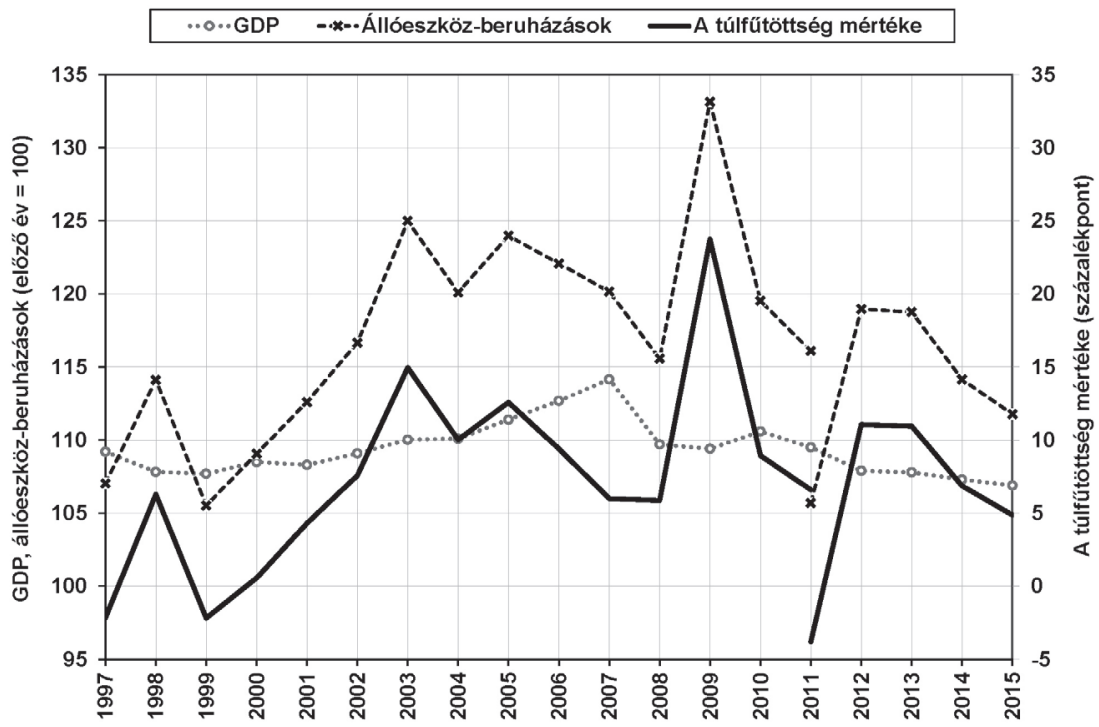

Megjegyzés: A 2011-es „szakadás” a beruházási adatok számbavételi módszertanának változásából fakad. A görbe 2011-ig a régi, 2011-tól az új módszertan szerint rögzített adatokra épül.

Adatok forrása: CSY $(2006,2016)$. 
Mint az a 2. ábrán látható, az állóeszköz-beruházások és a GDP növekedésének különbsége 1997 és 2015 között lényegében folyamatosan pozitív volt, vagyis a gazdaság túlfütöttsége folyamatosan jellemző az átalakuló kínai pártállami rendszer dinamikájára. Ez alól mindössze az 1997-es és az 1999-es esztendő jelent egyértelmü kivételt. (2011-ben - az akkor kivezetett régi számbavételi módszertan adatai alapján - szintén nem beszélhettünk a gazdaság túlfütöttségről. Az új módszertan adatai szerint, tehát 5 millió jüan felett, azonban igen.) Ezek a tények összhangban vannak az IPS-modell megállapításaival, amelyek szerint a túlfütöttség Kínában is a rendszer strukturális - állandó - sajátossága. ${ }^{12} \mathrm{Az}$ ábra azt is illusztrálja, hogy sokkhatások esetén a túlfütöttség mértéke megnő, mivel ilyenkor intenzívebbé válhat a rendszerszerü - politikailag racionális - gazdasági magatartás az elosztásban, a forrásvonzásban és a beruházásban. Ez utóbbiak következtében felerősödik a növekedési hajsza, a beruházások felívelnek, a túlfütöttség amplitúdója növekszik (Csanádi 1997, 2006, 2014).

A fenti folyamatok akkor kezdenek lecsengeni, amikor a rendszer újratermelődésének erőforráskorlátai keményednek - hiány alakul ki -, vagyis lecsökken a rendszerbe jutó erőforrás mennyisége. Tartományi szinten is megvizsgáltuk a túlfütöttség mértékét és időbeli alakulását 2007-től, a globális válság előtti utolsó esztendőtől 2015-ig. Az eredményeket mutató térképsorozatból (3. ábra) kitűnik, hogy a túlfütöttség az elméleti állításainknak megfelelően folyamatosan jellemző nemcsak a kínai nemzetgazdaságra, hanem az ország tartományainak döntő többségére is, tehát a rendszer dinamikájának általános - önhasonló -, aggregációs szinttől független vonásáról van szó. Azokban az esztendőkben, amikor országos szinten gazdasági túlfütöttség volt jellemző, a statisztikai adatok szerint 30 tartomány ${ }^{13}$ közül 23-29-ben (jellemzően 27-29-ben) ugyanez volt a helyzet.

Megállapítható továbbá, hogy a túlfütöttség mértékének térbeli képe is változik időben, ami tükrözi az állami beavatkozás hatását a válság idején, valamint annak térbeli preferenciáit. Míg a válság elmélyülése előtt a túlfütöttségnek nem volt markáns regionális mintázata, 2009-ben - a krízisre adott állami reakció, a 4000 milliárd jüan értékủ állami élénkítő csomag idején - igen. Ekkor az erőforrások allokációjának fó kedvezményezettjei a középső és a nyugati tartományok voltak, ezért a túlfütöttség mértéke is ezekben volt a legnagyobb. Ugyanakkor a - válság előtt az ország gazdasági növekedésének fő motorját képező, a kínai export döntő részét adó - tengerparti térségben a túlfütöttség szerényebb méreteket öltött. Az élénkítő csomag lecsengésével, 2010-re, a gazdasági túlfütöttség markáns térbeli mintázata újból „leépült”. A túlfütöttség dinamikájának sajátos vonása nyilvánul meg ugyanakkor abban, hogy nemcsak a térbeli koncentráció, hanem a lecsengés eltérő, a preferált tartományokban lassabb üteme is tükrözi az elosztás preferenciáit. 2012-2013-ban, országosan újból növekvő - és megint inkább a nyugati és középső tartományokban mutatkozó - túlfütöttség lassú lecsengése a különböző országrészekben szintén eltérő 
3. ábra: A túlfütöttség mértéke (az állóeszköz-beruházások és a GDP növekedési ütemének különbsége) Kína tartományaiban évenként, reálértéken, százalékpontban (2007-2015) Overheating intensity (the difference of fixed asset investment and GDP growth rates) in Chinese provinces at constant prices, in percentage points (2007-2015)

2007

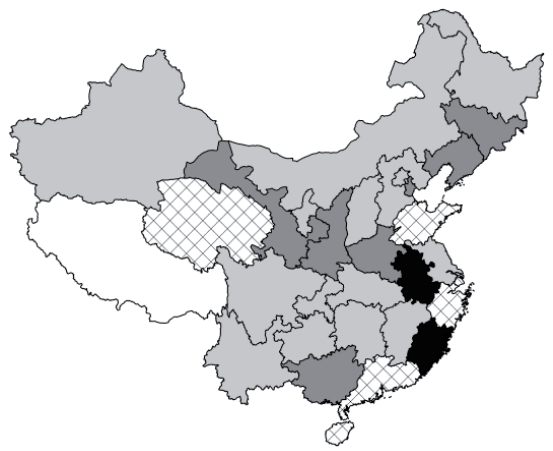

2009

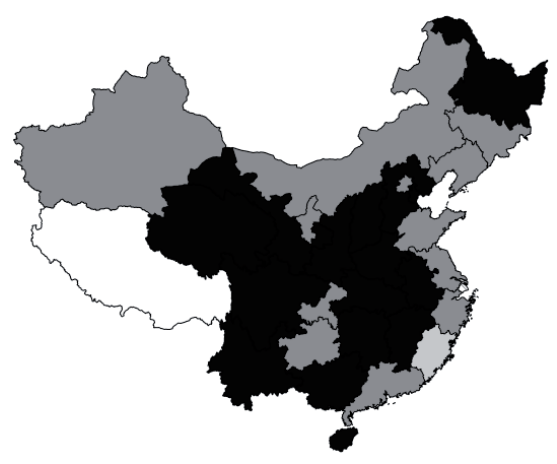

2011

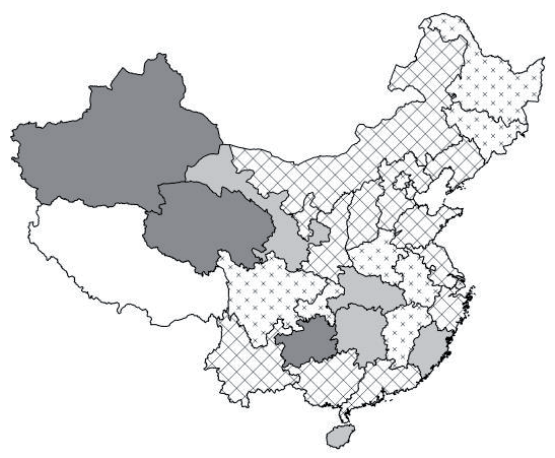

2008

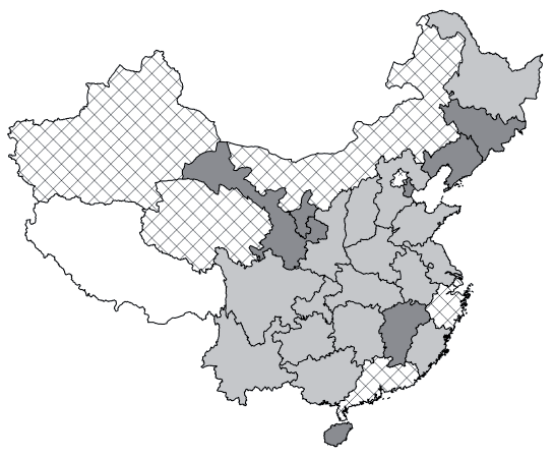

2010

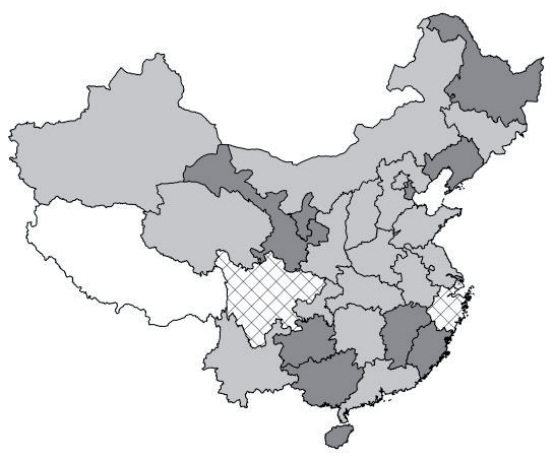

2012

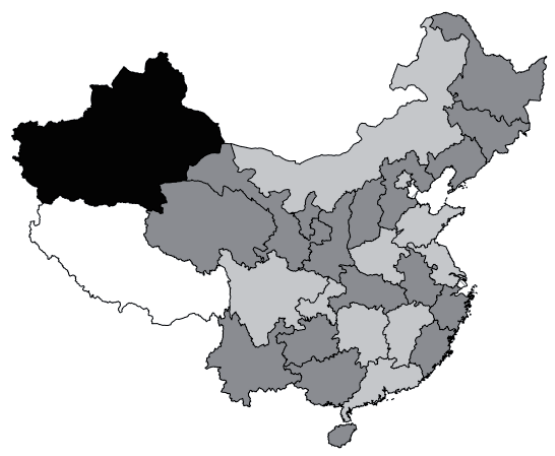



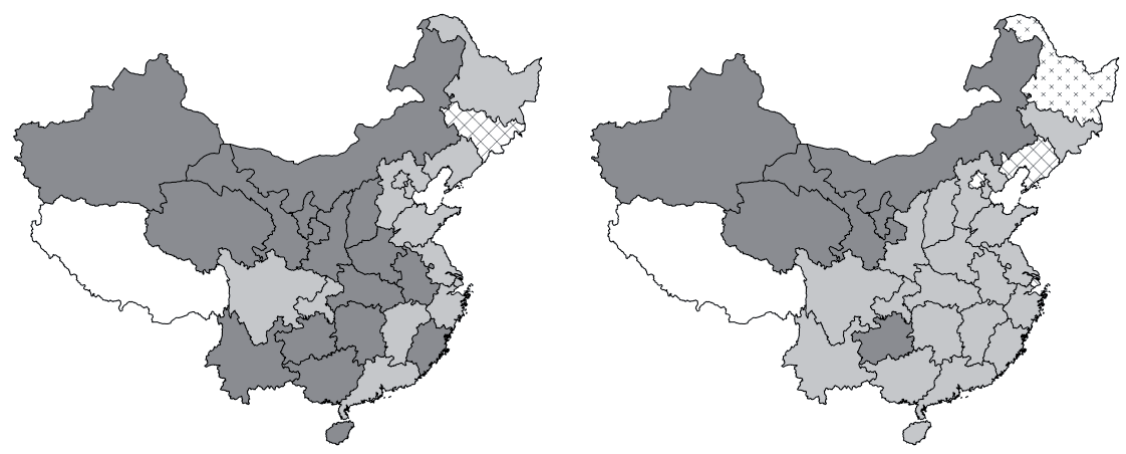

2015
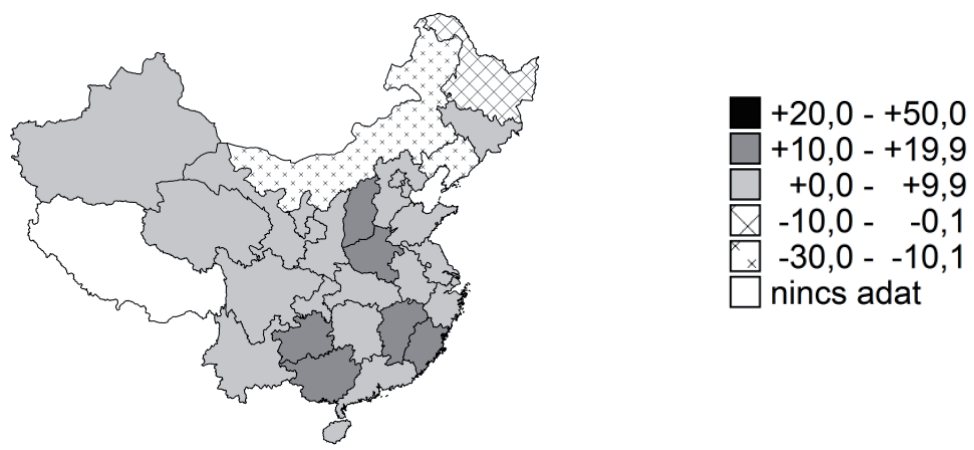

Adatok forrása: CSY (2007-2016).

ütemben haladt: a keletebbi zónában gyorsabban, a többi térségben, különösen a tekintélyes bányászati profillal rendelkező és az állami beruházások által erősen preferált nyugati, északnyugati területeken lassabban. Jellemző, hogy míg a keleti tengerparti térségben egyetlen tartomány (Fujian) kivételével 2013-ra már mindenhol 10 százalékpont alá süllyedt a túlfütöttség mértéke, sok belső tartományban ugyanez csak 2014-ben, a nyugati-északnyugati, döntően bányászati zónában (Xinjiang, Qinghai, Gansu, Ningxia, Észak-Mongólia) pedig csak 2015-ben következett be.

A túlfütöttség mértékének térbeli és időbeli jellegzetességei azt az elméleti állításunkat is alátámasztják, hogy a beruházások túlfutásának és a gazdasági túlfütöttségnek a mértéke a beavatkozások preferenciái szerint eltérően alakul, és ez a szelektivitás a túlfütöttség lecsengésekor is érvényesül. Az újratermelödési korlát keménysége, illetve puhasága követi az elosztási preferenciákat. Ez a sajátosság nemcsak térben, hanem vállalati tulajdontípusok szerint is kimutatható. Ebből a szempontból fontos összefüggéseket tár föl az állami és a nem állami beruházások országos szintü ütemét mutató 4. ábra, különösen a túlfü- 
4. ábra: Az állami tulajdonú és állami irányítás alatt álló, valamint a többi vállalat beruházásainak változása Kínában, havonként, a megelőző év azonos hónapjához mérten

(2005. január-2016. december)

Investment growth rate by state-owned and state-controlled, and non-state owned, non-state controlled enterprises (monthly data compared to corresponding month of the previous year) (January 2005-December 2016)

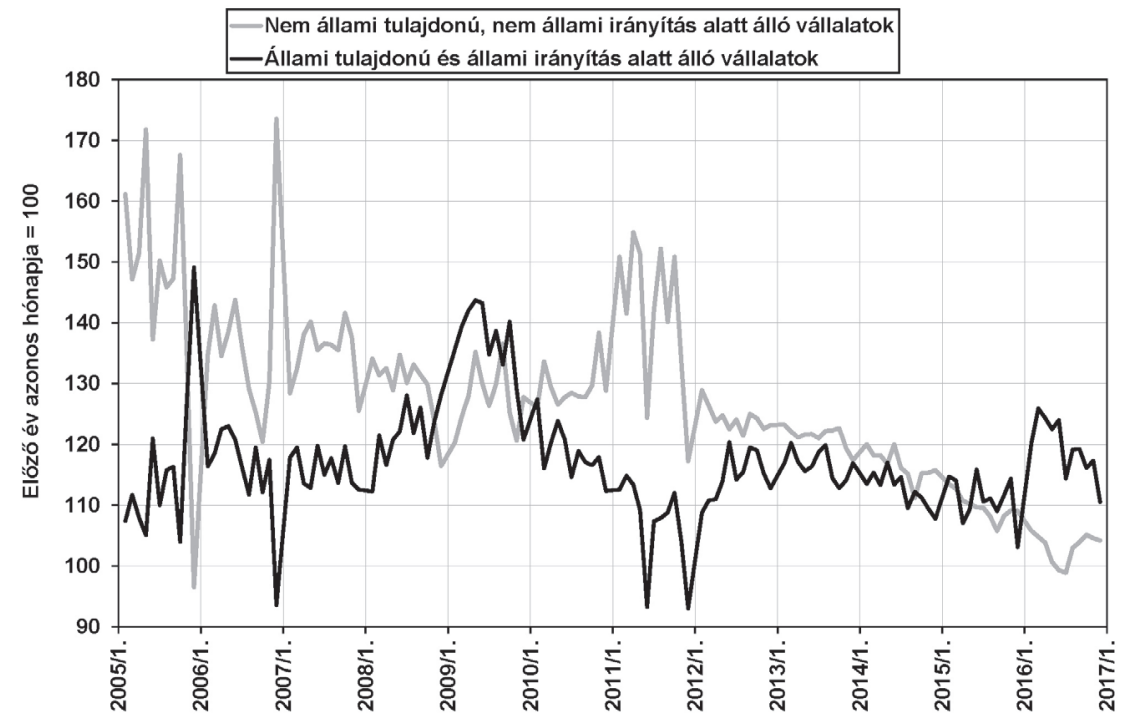

Adatok forrás: NBSC (é. n.).

töttség mértékének változásaival (2. ábra) összefüggésben. Azt láthatjuk, hogy a 2009-es élénkítő csomag előtt az állami tulajdonú és állami irányítás alatt álló vállalatok beruházásai lassabban nőttek, mint a többi vállalatéi. Ebben az időben - az élénkítő csomag alkalmazása előtt - az állami beruházások túlfutásának mértéke alacsonyabb volt, mint alatta és utána. A 2. ábrán látható országos gazdasági túlfütöttséghez tehát ekkoriban a hálón belüli rész kevésbé járult hozzá. A 2009-es élénkítő csomag révén megugró gazdasági túlfütöttség ugyanakkor a hálón belül jelentkezett erősebben, azon kívül gyengébben. ${ }^{14}$

A beruházási dinamika 2011-ben bekövetkezett lassulásáért alapvetően a hálón belüli szféra volt a felelős, ahol abban az évben minimálisra csökkent, sőt egyes hónapokban megszűnt a túlfutás, miközben a hálón kívüli vállalatok beruházásai megugrottak. Az országos túlfütöttség 2012-2013-as emelkedése a pártállami hálón belüli vállalatok beruházási ütemének újabb növekedéséből következett, míg a következő évek „lecsengése” a hálón kívül és belül egyaránt jelentős volt. Az, hogy a beruházási ütem kezdetben valamelyest nagyobb mértékben esett vissza a hálón kívül, azt jelezheti, hogy a beavatkozások által nem preferált vállalatok gyorsabban reagáltak a visszafogásra. (Figyelemre méltó, hogy 2016-ban a hálóhoz köthető beruházások mértéke újból megugrott, miközben a hálón kívülieké a megelőző évekhez hasonlóan lassan, de stabilan to- 
vább csökkent. Ennek részletes elemzésére ugyanakkor csak a 2016-os ágazati és területi adatsorok publikálását követően nyílhat majd lehetőség.)

A fent leírt trendeket a pártállami átalakulás dinamikája szempontjából is értelmezhetjük. A grafikon alátámasztja azt a feltételezést, hogy amikor nagyobb mennyiségű erőforrás áramlik a gazdaságba, felerősödik a rendszerre jellemző - a nagy állami vállalatokat kedvezményező - szelekció az elosztásban. Ez a tulajdoni preferencia, amely a 2008-ban bevezetett, döntően 2009-ben megvalósuló élénkítő csomagban is megjelent, az állami beruházások dinamikája alapján a háló aktivitását, illetve kiterjedését, vagyis a gazdasági átalakulás lassulását vonta maga után. A kiterjedés 2010-ig tartott, majd a beruházási hullám ezt követő lecsengése a háló visszahúzódását, vagyis az átalakulás felgyorsulását is jelezte. A hálóbeli vállalatok beruházásainak növekedése 2012-ben újra felgyorsult, de már nem haladta meg a többi vállalat beruházásainak növekedési ütemét, sőt többnyire - kismértékben - elmaradt attól. Ekkor tehát a nem állami szféra beruházásai gyorsabb ütemben nőttek a hálóéinál (relatív zsugorodás), vagyis az átalakulás tovább gyorsult, egészen 2015-ig, amikor a háló az egyéb vállalatok beruházásaihoz képest újra elkezdett kiterjedni, előbb igen szerény mértékben, majd 2016-ban rendkívül markánsan.

Az a tény, hogy a gazdasági túlfütöttség mértékének 2009-es megugrásakor a pártállami háló beruházása átmenetileg erősebben megemelkedik, igazolja az állami beavatkozás (az élénkítő csomag) hivatalosan is kinyilvánított tulajdoni preferenciájának érvényesülését. Más szóval az átalakulás lelassulása és felgyorsulása a különböző - kevésbé vagy jobban preferált - tulajdonformájú vállalatok beruházásainál eltérően jelentkezik. 2010 vége és 2012 eleje között - a beruházások központi visszafogásának hatására - az állami beruházások növekedése jelentősen lelassult, néhány hónapban pedig csökkenés következett be, miközben a nem állami beruházások növekedése átmenetileg fokozódott.

Utóbbi tendencia - feltételezésünk szerint - több tényezőből is fakadhat. Egyrészt abból, hogy az állami beruházások által preferált térségek (döntően a középső és a nyugati országrészben) és vállalati tulajdonformák (különösen a pártállami hálóhoz tartozó vállalatok) inputigénye az állami beruházások visszafogásának idején is magas maradt, a nem állami vállalatok pedig - kis időbeli eltolódással - ennek hatására hajtottak végre pótlólagos beruházásokat. Ez azt jelentheti, hogy a nem állami beruházások - az állami beruházások csökkenésére reagálva - végeredményben kompenzálják a túlfütöttség lecsengését, együttmozgásukkal pedig növelik a túlfütöttség amplitúdóját, különösen az állami beruházások által egyébként preferált térségekben és vállalattípusoknál. ${ }^{15}$

Másik lehetőség, hogy az állam által preferált területek beruházásainak lecsengésekor a nem állami vállalatok visszatérnek korábbi beruházási preferenciáikhoz, és ez képeződik le a 4. ábra országos adatsoraiban. A fenti két feltételezés helytállóságát, valamint esetleges egyéb mechanizmusok jelenlétét ugyanakkor csak vállalati szintű adatok elemzésével, kutatásunk későbbi fázisában lehet majd megfelelően feltárni. 
A beruházások fluktuációjának makroszintű jelensége mögött a különböző tulajdoni hátterű vállalatok eltérő magatartása húzódik. Ennek vizsgálatára vállalattípusonként külön-külön - Gyuris (2015) korábbi elemzéseit időben folytatva - Pearson-féle lineáris korrelációkat számítottunk a tartományok egy főre jutó GDP-je, valamint egy före vetített állóeszköz-beruházásaik között (5. ábra). A számításokkal azt kívántuk megállapítani, mennyiben figyelhető meg az egyes vállalattípusoknál az a globális válság előtti nemzetgazdasági trend, hogy a kínai állam az országos növekedés felsrófolása végett aránytalanul nagymértékben összpontosította saját beruházásait - és „terelte” a többi szereplőjét is - a legfejlettebb tengerparti tartományokba (Meng 2003; Nemeskéri 2003). Kiemelten figyeltünk az állami vállalatok, a kft.-k és a hazai magánvállalatok magatartásának elemzésére, mivel, ahogy az 1. ábra mutatta, ezek adják az összes beruházás döntő hányadát (a 2000-es évek közepén több mint 70, 2015-ben több mint 80\%-át).

Az eredmények azt mutatják, hogy a 2000-es évek közepéig valamennyi fontosabb szereplő erőteljesen a fejlettebb tartományokba összpontosította beruházásait. Ez alól az állami vállalatok sem jelentettek érdemi kivételt. Ugyan az ő esetükben - az ezredforduló után, a nyugati országrészek felzárkóztatására indított állami programok hatására (Goodman 2004) - lassan megindult a beru-

5. ábra: A különböző tulajdoni hátterű állóeszköz-beruházások egy főre jutó értékének a GDP/fő mutatóval való lineáris korrelációs együtthatója Kínában, tartományi szinten (1995-2015)

Linear correlation coefficient of per capita investment by various enterprise ownership types and per capita GDP in Chinese provinces (1995-2015)

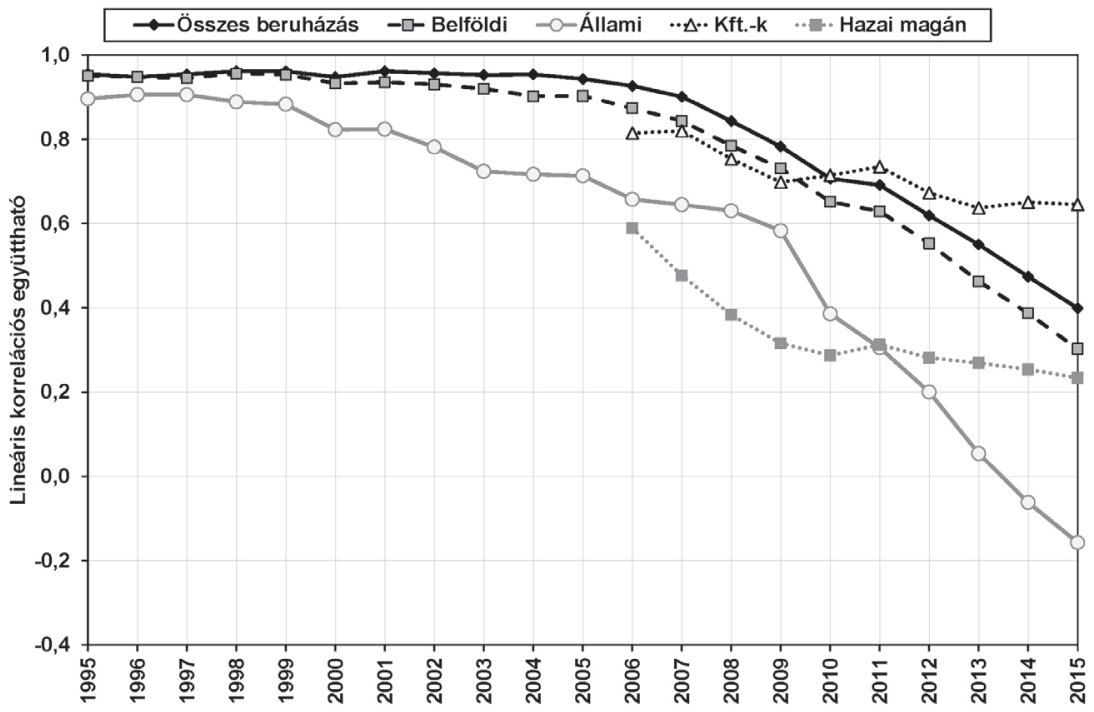

Adatok forrása: CSY (1996-2016). 
házások szélsőséges térbeli elosztásának „olvadása”, 2009-ig nem történt markáns változás. ${ }^{16} \mathrm{Az}$ élénkítő csomag kezdetétől viszont az állami vállalatok beruházási stratégiája gyorsuló ütemben és trendszerüen mozdult el a kevésbé fejlett területek irányába. 2014 óta pedig, ha szerény mértékben is, a beruházási stratégia már jobban preferálja az elmaradottabb területeket a fejlettekkel szemben. ${ }^{17}$ Mindeközben a többi meghatározó szereplő közül a hazai magánvállalatok beruházásai 2006, a kft.-k beruházásai pedig 2007 után kisebb mértékben elmozdultak a fejlett térségek egyoldalú preferálásától, de az ő beruházási stratégiájuk továbbra is inkább a fejlett térségekre összpontosít (a kft.-ké különösen erősen).

Összességében azt mondhatjuk, hogy az átalakulás folyamata rövid távon nem egyirányú, illetve a különböző vállalattípusoknál nem azonos sebességü. Hátterében hol a háló relatív és abszolút zsugorodásának időbeli váltakozása, hol a relatív és az abszolút zsugorodás egyidejű jelenléte rejlik. Ezek a sajátosságok a háló belső szelekciós mechanizmusa következtében a beruházások fluktuációjának és a túlfütöttség mértékének általános dinamikájával, valamint a különböző vállalattípusok eltérő vállalati magatartásával függenek össze. A háló azonban az alkalmi és átmeneti kiterjedések idején is jellemzően visszaszorul relatív értelemben (az összes beruházás növekedési üteméhez képest), a privát szféra beruházásainak önmagukhoz és a hálóhoz képest is gyorsuló kiterjedése révén. Jellemző, hogy az állami beruházások értéke kisebb fluktuációkkal 1980 óta végig a GDP 15-22\%-a között mozgott. Az egyéb beruházások megfelelő értéke a GDP-hez viszonyítva ugyanakkor gyorsuló ütemben növekedett, az 1980-as 3,6\%-ról 2000-ig 16,3\%-ra, a globális válság 2008-as kitöréséig 38,9\%-ra, majd egy újabb jelentős gyorsulással 2015-ig 61,6\%-ra (Gyuris 2015). (Az értékek az adott évben indult, valamint a korábbi években kezdődött, de áthúzódó beruházásokat is tartalmazzák.)

A háló fokozatos zsugorodása során a hatalmi háló önhasonló működésének sajátosságai nem változnak. Ugyanezt a túlfütöttséggel összefüggő időszakos lüktetést és az élénkítő csomag térbeli és tulajdonbeli preferenciájának hatását tapasztalhatjuk tartományi szinten is a háló szempontjából (6. ábra). Bár az alapséma ebben az esetben is az állami vállalatok fokozatos visszaszorulása az összes beruházáson belül, a tartományi tendenciák erősen követik az országos folyamatokat. Amikor országosan csökkent az állami beruházások aránya (leginkább 2007-ben és 2010-2011-ben), a 31 tartomány közül 23-27-ben ugyanez történt. Ellenben az állami beruházások nemzetgazdasági súlyának növekedésekor (2009-ben, illetve kismértékben 2015-ben) 22-25 tartományban ezzel megegyező irányú változás következett be, a legerősebb növekedéssel a belső országrész államilag preferált térségeiben.

A korábban rögzített eredményekkel összevetve ez azt jelenti, hogy 2009ben - amikor a túlfütöttség amplitúdójának növekedése (2. ábra), a tartományok zömére való kiterjedése (3. ábra), valamint az országos gazdaságpolitika által preferált térségekben való különösen erős fokozódása (3. ábra) volt jel- 
6. ábra: Az állami vállalatok részesedésének változása az adott tartomány összes állóeszköz-beruházásából az előző évhez képest Kínában, százalékpontban (2007-2015) Annual changes of state-owned enterprises' share of total investment in fixed assets in Chinese provinces, in percentage points (2007-2015)
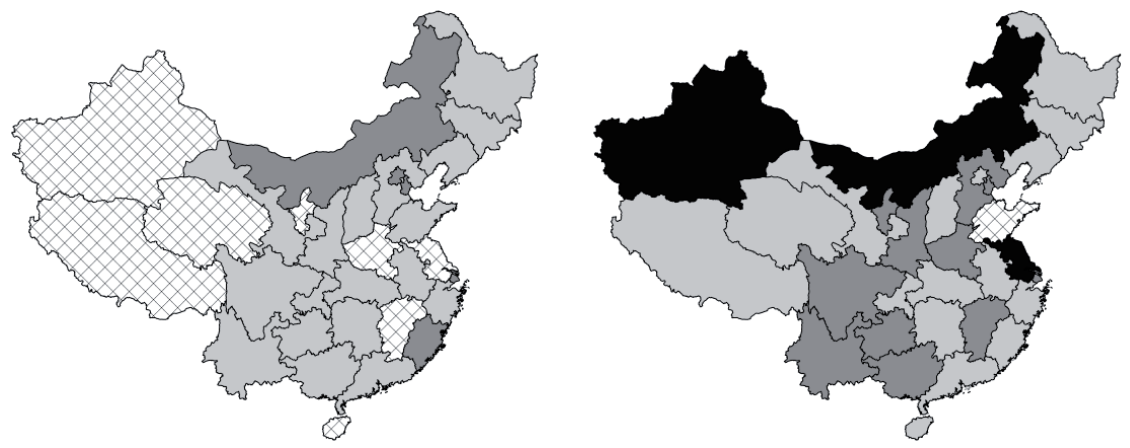

2009

2010
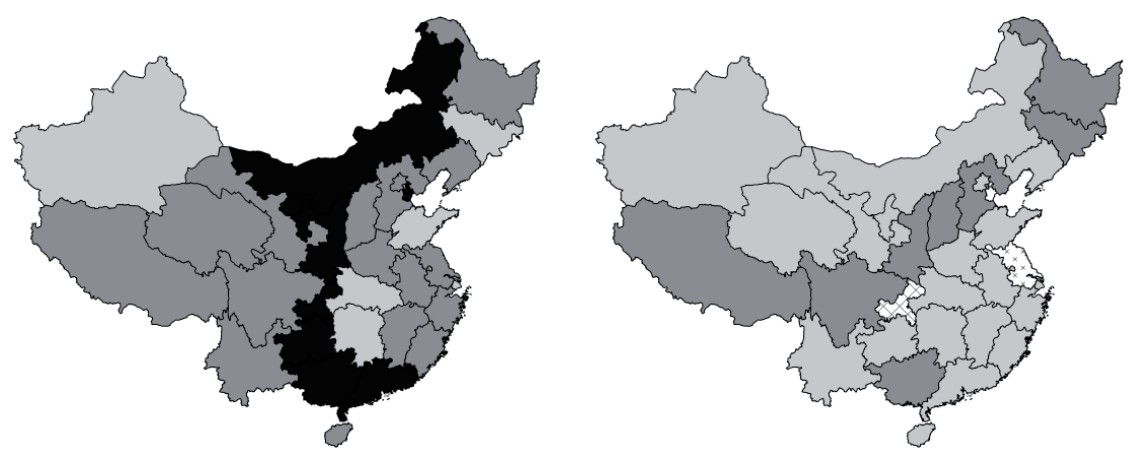

2011

2012
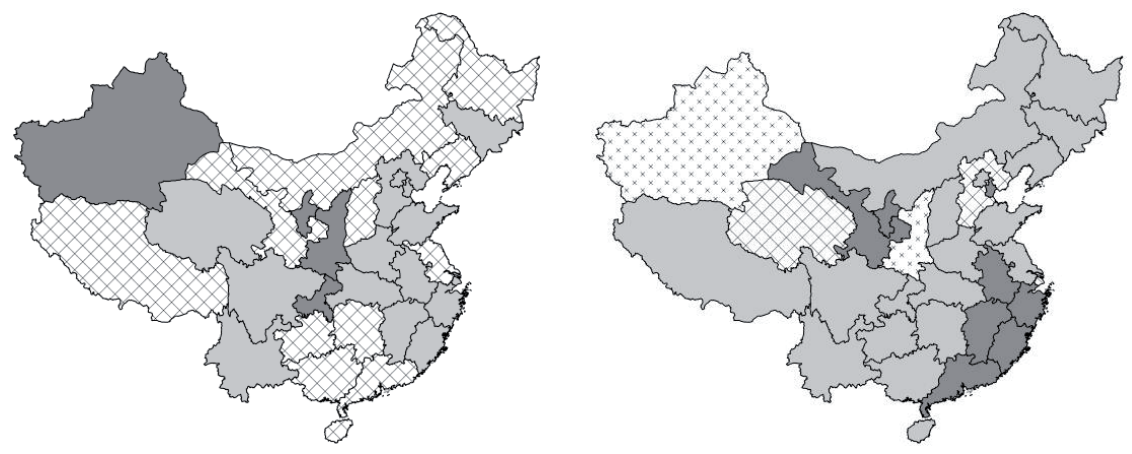

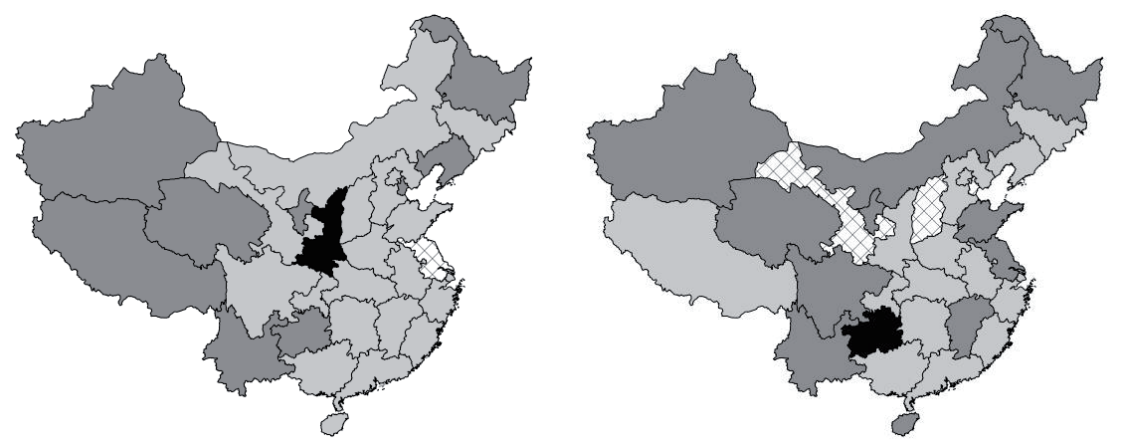

2015
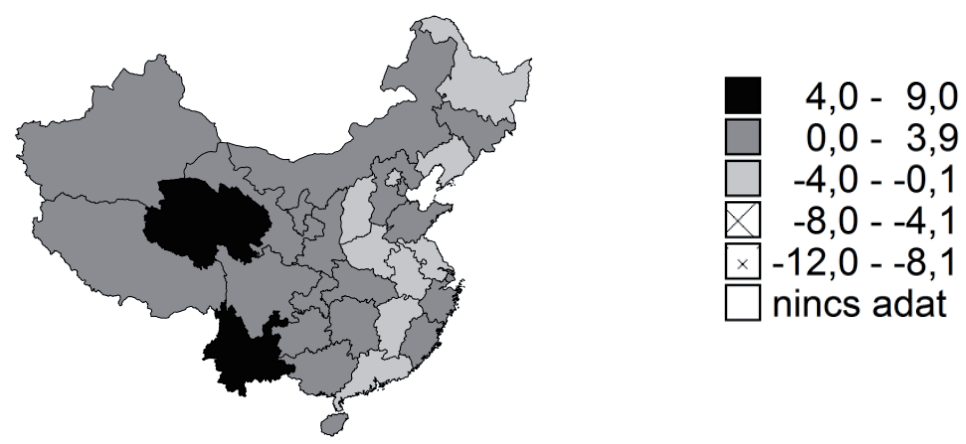

Adatok forrása: CSY (2007-2016).

lemzo - a pártállami háló beruházásai átmenetileg nagyobb ütemben nőttek, mint a hálón kívüli vállalatokéi (1. és 4 . ábra). Ugyanebben az évben a háló átmenetileg jelentősen kiterjedt a tartományok többségében is, leginkább a preferált és a gazdaságilag erősebben túlfütött középső tartományokban (6. ábra). 2010-ben már csak a középső tartományoknál nőtt a háló az előző évhez képest, vagyis a korábban preferált területek és tulajdontípusok esetében a beruházások túlfutása lassabban csengett le 2011-ben. A beruházások központi visszafogásakor már csak három középső és egy nyugati tartománynál, majd 2012-ben a keleti, 2013-ban pedig újra a nyugati tartományokban terjedt ki a háló. Vagyis ez esetben azt láthatjuk, hogy a preferenciák késleltetik a háló visszahúzódását.

A háló tendenciaszerủ zsugorodása a beruházások forrás szerinti megoszlásában is tetten érhető: a saját forrásból eszközölt beruházások aránya a belföldi hitelből és az állami költségvetésből végrehajtott beruházásokat messze meghaladva az elmúlt tíz esztendőben folyamatosan növekedett, ami szintén a hálón kívüli szféra további terjeszkedését, a háló relatív és abszolút visszahúzódását jelzi az átalakulás folyamatában (7. ábra). 
7. ábra: Az állóeszköz-beruházások forrás szerinti szerkezetének alakulása Kínában (2004-2015) Investment in fixed assets by sources of funding in China (2004-2015)

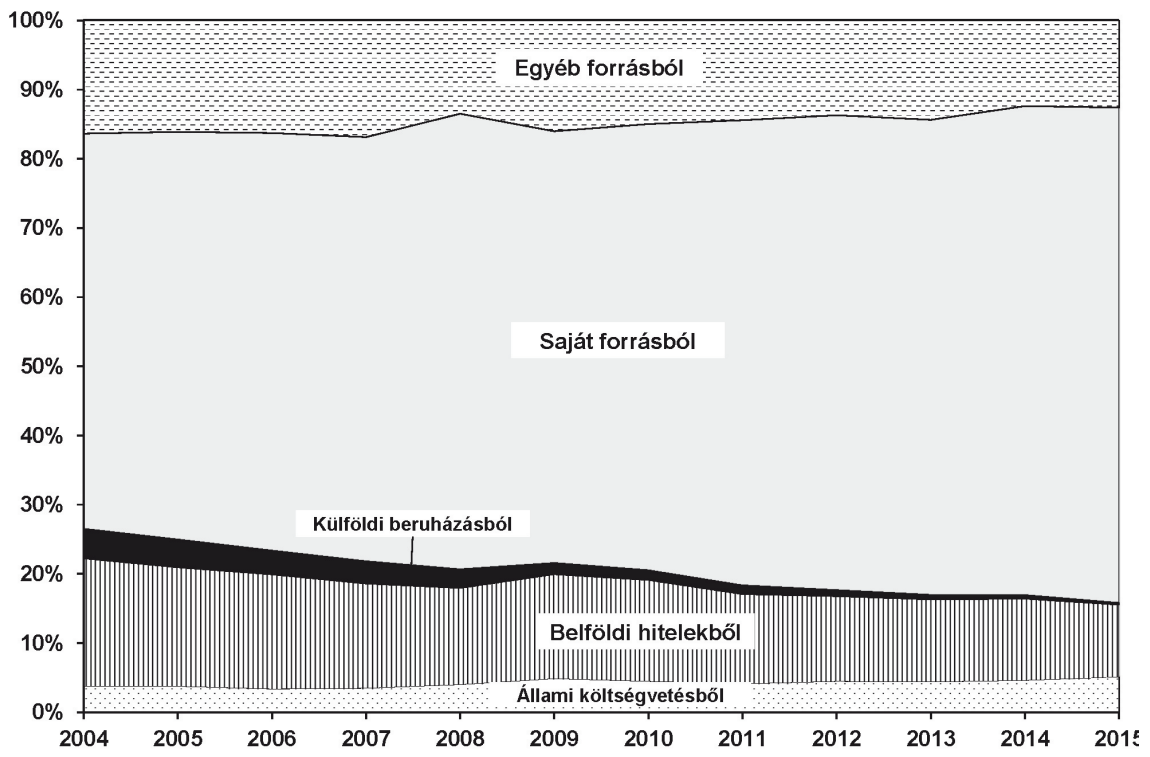

Adatok forrása: CSY (2016).

Megállapítható az is, hogy - a háló országos szinten folyamatosan zajló abszolút és relatív visszahúzódása mellett - a decentralizált hatalmi szerkezet tovább erősödik, a hálón belüli decentralizáló reformok, valamint a hálón kívüli szféra lokális terjeszkedése következtében. A központi kormányzat csökkenő beruházási részesedésének dinamikáját mutatja a központi és lokális kormányzatok beruházási értékének növekedési üteme. A központosító szándékú 1994-es adóreform (Csanádi, Lai 2003) ellenére az ezredforduló óta folyamatosan nő a lokális kormányzati beruházások súlya, illetve nagyobb azok növekedési üteme. Ennek eredményeként a központi kormányzat beruházásainak részaránya az 1998-as 30,8\%-ról 2008-ra 11,2\%-ra csökkent, 2016-ra pedig - a trend felgyorsulásával - 4,2\%-ra.

A 8. ábra pedig azt mutatja, hogy szemben a 2004-es időszakkal, amikor a központi állami beruházások túlfutása okozta a gazdaság túlfütöttségét, 2009-től 2012-ig éppen a központi állam próbálja a túlfütöttséget visszafogni a központi beruházások lassításával, a bankok hitelezéseinek szigorúbb szabályozásával, kötelező tőkeemeléssel és egyéb szabályozók szigorításával (Csanádi 2014). Az intézkedések azonban a decentralizált pártállami háló következtében jórészt csak a központi beruházásoknál hatnak (2011 és 2012 hónapjaiban a 8. ábrán), miáltal a központ forráselosztó képessége visszaszorul a lokális szintek javára. 
8. ábra: A központi kormányzat és a helyi kormányzatok által végrehajtott állóeszköz-beruházások, továbbá az összes beruházás értékének változása Kínában, havi bontásban, az előző év megfelelő hónapjához viszonyítva (1999. január-2016. december)

Growth rate of investment in fixed assets by the central government, investment in fixed assets by local governments, and the total investment in fixed assets in China; monthly values compared to corresponding month of the previous year (January 1999-December 2016)

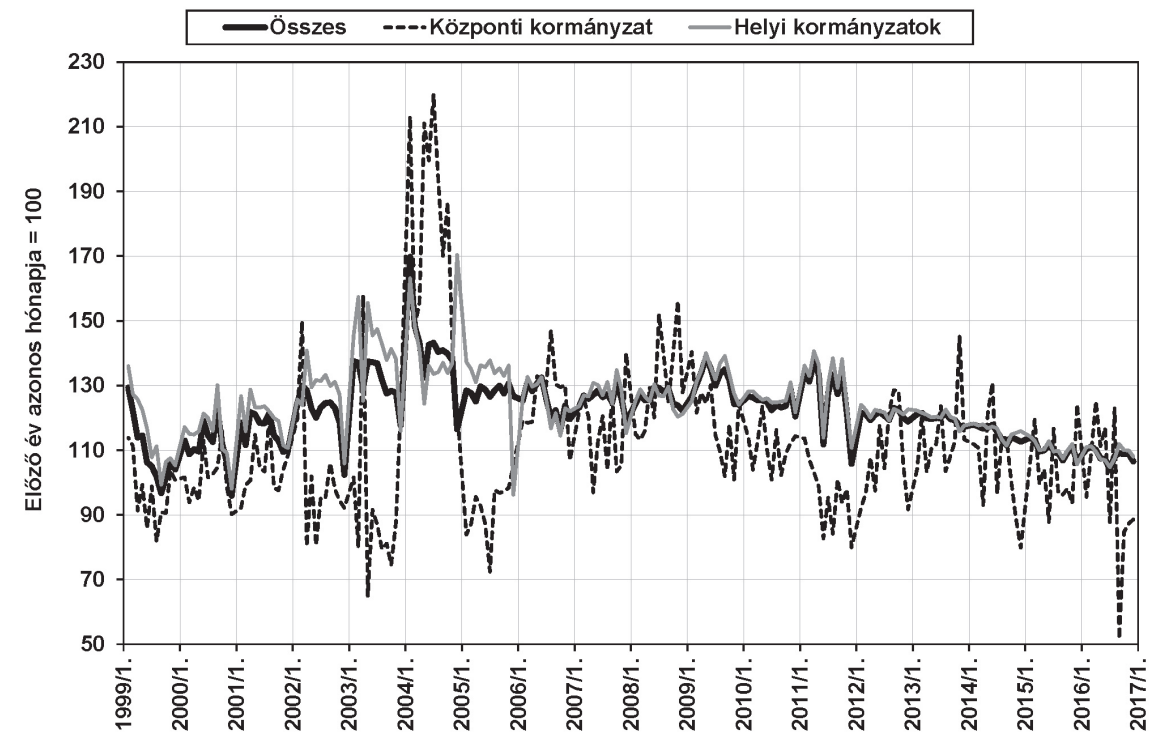

Adatok forrása: NBSC (é.n.).

\section{Összefoglalás}

A beruházások és a gazdasági túlfütöttség dinamikáját az átalakuló kínai pártállami rendszerben vizsgáltuk egy összehasonlító pártállami modell keretében értelmezve. Rámutattunk arra, hogy a beruházások túlfutását, valamint a gazdaság ebből fakadó túlfütöttségét a párt, az állam és a gazdaság döntéshozói közötti függőségi és érdekérvényesítési viszonyokból alakult pártállami hatalmi háló, illetve az abban keletkező szerkezeti motivációk okozzák. Ezért a pártállamokban a túlfütöttség állandó jellegzetesség. Ez az összefüggés rendszerszerü, a háló sajátja, ezért a háló abszolút és relatív visszahúzódásától - a gazdasági rendszer fokozatos átalakulásától - függetlenül is érvényesül. Ez az általános sajátosság a pártállamok önhasonló hatalmi szerkezete következtében a kínai pártállami rendszer egészében és annak különböző aggregációs szintjein is kimutatható. 
Megállapítottuk, hogy a fenti sajátosságok - a hálót érő külső megrázkódtatás (globális válság) hatására - az erőteljesebb állami beavatkozások következtében intenzívebbé válnak, időszakosan megnő a túlfütöttség amplitúdója. A túlfütöttség időszakos „kilengése” az országos szinttel egy időben tartományi szinten is megjelenik. A kínai decentralizált hatalmi hálóban a kilengés amplitúdója tartományi szinten az országosnál nagyobb, a legnagyobb amplitúdó az államilag preferált területeken (tartományokban) figyelhető meg. Bemutattuk azt is, hogy a beruházások, illetve a túlfütöttség kilengésének és lecsengésének, valamint a háló kiterjedésének és zsugorodásának dinamikája összefügg: a túlfütöttség átmeneti kilengése esetén a háló - mind országos, mind tartományi szinten - átmenetileg kiterjed, legerősebben a preferált területeken. Sőt, az átalakuló kínai gazdaságban a túlfütöttség amplitúdója azért is megnő, mert a hálón kívüli szféra igazodik a háló preferenciáihoz (mind területi értelemben, mind a vállalati tulajdontípusok szempontjából).

A túlfütöttség lanyhulásával a háló abszolút és/vagy relatív értelemben zsugorodik, mind országos, mind tartományi szinten. A lecsengés azonban differenciált: a decentralizált hatalmi eloszlás következtében a túlfütöttség lanyhulása, valamint a háló zsugorodása a helyi kormányzatok beruházásai esetén lassabb, mint a központi beruházásoknál. A folyamatosan decentralizálódó kínai hatalmi szerkezet következtében ugyanis a beruházások központi visszafogása kevésbé befolyásolja a lokális beruházások túlfutását, a helyi kormányok eladósodását és vele az önhasonló szerkezet belső motivációit. Ezen felül a túlfütöttség lanyhulása, valamint a háló zsugorodása lassúbb a preferált térségekben.

Hasonló differenciálódás tapasztalható vállalati tulajdonformák szerint is. Az átalakulási folyamat során ugyanis a hálóhoz tartozó és az azon kívüli vállalatok mind túlfütöttség, mind annak lecsengése esetén eltérően viselkednek. A túlfütöttség időszakában a legnagyobb beruházási súllyal bíró hálón kívüli vállalattípusok beruházásai is valamelyest az államilag preferált területek irányába tolódnak el, de sokkal kisebb mértékben, mint a hálón belüli vállalatokéi. Lecsengéskor ez az eltolódás a hálón kívüli vállalatoknál véget ér, vagy akár visszarendeződés történik a korábban általuk preferált (jellemzően fejlettebb) tartományokba, míg a hálóhoz tartozó vállalatok efféle visszarendeződő magatartást kevésbé vagy egyáltalán nem mutatnak. A globális válságot kompenzáló beavatkozások által okozott rövid távú pulzálás ellenére hosszú távon a háló abszolút és relatív zsugorodása, tehát az átalakulás folyamata országos és tartományi szinten is megfigyelhető.

\section{Jegyzetek}

1 Ugyanez jórészt érvényes azokra a területi szemléletű munkákra is, amelyek különösen város-vidék vonatkozásban mutattak rá a kelet-európai pártállami beruházások aránytalan és 
növekvő egyenlőtlenséget generáló elosztására (Barta 2002; Beluszky 1999; Meusburger 1997; Nemes Nagy 1987; Szelényi 1990; Vági 1982). A néhány kivételre, tehát a kelet-európai és a kínai szocialista pártállami rendszerek területi egyenlőtlenségi folyamatait összevető munkára példaként említhető Frolic (1976) és Gyuris (2014).

2 A Kínában dolgozó kutatók vonatkozó publikációit kínai kolléganőnk, Wang Wanjun (Nanjing University of Finance and Economics) segítségével igyekeztünk áttekinteni a kilencvenes évek közepétől napjainkig.

3 Ebből a megközelítésből az is következik, hogy az állami beavatkozásokat, valamint a beruházások túlfutását a pártállamok rendszerbeli szabályszerűségének tekintjük, nem pedig gazdaságpolitikai vagy egyéb természetű „anomáliának”.

4 Ilyenek például: fejlesztő állam, államkapitalizmus, szocialista piacgazdaság, feltörekvő rendszer, hibrid rendszer, változatos (variegated) kapitalizmus, polimorf állam, töredezett (fragmented) autoritarianizmus, központosított fejlesztő autokrácia, instrumentális fejlesztő állam, klientúraépítő állam.

5 Bár az IPS-modell - a legelső változatai óta - mindvégig a rendszerparadigma gondolatára épült, ezt a fogalmat csak Kornai cikkeinek megjelenése után alkalmaztuk először, hogy megvilágítsuk az ő, valamint az IPS-modell közötti szemléletbeli, tartalmi eltérést.

6 Természetesen ez nem jelenti azt, hogy a kommunista pártállamokon kívül máshol - így akár a globális gazdasági centrumhoz tartozó kapitalista országokban - időszakonként ne volna kimutatható túlberuházás, valamint ebből fakadóan felesleges kapacitások létrejötte. Míg azonban ott ezek általában nem tartanak ki néhány évnél tovább (jellemzően válságok előtt és alatt), a kommunista pártállamokban tartós, a rendszer „normál” működéséhez tartozó jellemvonásnak számítanak.

7 A pártállam hatalmi szerkezetének főbb típusairól, valamint az újratermelődés és az átalakulás dinamikájának ezekre jellemző sajátosságairól, ehhez kapcsolódóan pedig a kínai pártállam hatalmi-szerkezeti és intézménytörténeti specifikumairól részletesen lásd Csanádi (2006, 2016a).

8 A kínai (gazdaság)statisztikai adatok megbízhatóságát részletesebben elemzi Jordán (2009).

9 Példának hozzuk Borio (2012) pénzügyi ciklusokról szóló elméletét és gyakorlati számításait, amelyekben a hitelek fluktuációjának mértékét a sokéves átlaghoz viszonyítja.

10 A túlfütöttség fogalmának - bár használata több szakmában és a szakmai közbeszédben is elterjedt - nincs egyetlen, általánosan elfogadott számszerűsítési metódusa. Mi az említett egyszerű mutatót használjuk a tanulmányban.

11 Megjegyezzük, hogy a Kínai Statisztikai Hivatal 2011-ben módszertani változtatást hajtott végre a beruházási adatok gyüjtésében: míg korábban minden 500000 jüan feletti beruházást figyelembe vettek, 2011 után már csak az 5 millió jüant meghaladókat. Ez - a mindkét módszerrel közzétett 2010-es adatok szerint - a korábban számba vett teljes beruházástömeg 9,5\%-át zárta ki az összeírásból, ami arra utal, hogy a váltás előtti és utáni időszak adatsorai, kellő körültekintéssel, fö vonalakban összevethetők.

12 Ehhez hasonló strukturális és motivációs sajátosságra sem az EU egészében, sem az eurózónában, sem az EU nyugat-európai tagállamaiban, sem az USA-ban nem következtethetünk a beruházási és a GDP-adatok (valamint a túlfütöttség ezekből számított mértéke) alapján. (Az Eurostat 2005-2016-os, valamint a US Department of Commerce, Bureau of Economic Analysis 1990-2016-os adataiból előállított számítási eredményeket a szerzők kérésre rendelkezésre bocsátják.)

13 Tibetre nem közlik a beruházások árindexének éves változását a Kínai Statisztikai Hivatal évkönyvei, így a beruházások reálnövekedésének, valamit a beruházási többlet értékének pontos kiszámítása nem lehetséges.

14 A 4. ábra a beruházások nominálértéken számolt növekedését mutatja, mivel a reálértékre való átszámoláshoz szükséges havi beruházási árindexek értéke a Kínai Statisztikai Hivatal honlapján nem érhető el. A grafikon funkciója ugyanakkor az, hogy az állami és a nem állami beruházások növekedésének egymáshoz viszonyított dinamikáját tükrözze, vagyis adott időpontra mutassa a két görbe egymáshoz illeszkedő pozícióját. Ez az elvárás a nominálértéken számolt adatokkal is teljesül. 
15 Ezt a feltételezésünket támasztja alá számszerủen Liu és Spiegel (2017), akik cikkükben azt bizonyítják, hogy a kötelező banki tartalékarányok felemelésekor, az állami vállalatoknak nyújtott hivatalos, költségvetésen belüli („on-budget”) hitel beszűkülésével növekszik a magánvállalatok számára nyújtott árnyékbankrendszer jellegü és költségvetésen kívüli („offbudget") típusú finanszírozás.

16 Egyedüli kivételnek a hazai magánvállalatok számítottak, amelyek beruházásai - elsősorban a közlekedési és távközlési fejlesztések eredményeire, a tengerparthoz relatíve közelebb eső középső tartományok javuló elérhetőségére reagálva - már a válság előtt is egyre kevésbé koncentrálódtak a legfejlettebb tartományokban (igaz, a fejlettebb térségek így is előtérben maradtak).

17 A kínai vezetés ugyanis ettől reméli a hazai fogyasztópiac bővítését, a kínai termékek iránti nemzetközi kereslet csökkenésének ellensúlyozását, egyben a rendkívül nagymértékű regionális fejlettségi egyenlőtlenségekből fakadó társadalmi és politikai feszültségek kezelését, enyhítését (Gyuris 2015).

\section{Köszönetnyilvánítás}

Köszönjük Laki Mihály, Madarász Aladár, Soós Károly Attila és Voszka Éva hasznos koncepcionális észrevételeit, valamint Wang Wanjun szakmai segítségét. A tanulmány a Nemzeti Kutatási, Fejlesztési és Innovációs Hivatal (NKFIH) K 115932 és PD 121127 számú pályázatainak támogatásával készült.

\section{Irodalom}

Ahuja, A., Nabar, M. (2012): Investment-led growth in China: Global spillovers. IMF Working Paper, WP/12/267. https://www.imf.org/ /media/Websites/IMF/imported-full-text-pdf/external/ pubs/ft/wp/2012/_wp12267.ashx (Letöltés: 2017. június 2.)

Bajt, A. (1971): Investment cycles in socialist economies: A review article. Journal of Economic Literature, 1., 53-63.

Barta Gy. (2002): A magyar ipar területi folyamatai 1945-2000. Dialóg Campus, Budapest, Pécs

Bauer T. (1978): Beruházási ciklusok a tervgazdaságban. A reform előtti tervgazdaságok esete. Gazdaság, 4., 57-75.

Bauer T. (1987): Ciklusok helyett válság? Közgazdasági Szemle, 12., 1409-1434.

Beluszky P. (1999): Magyarország településföldrajza. Dialóg Campus, Budapest, Pécs

Borio, C. (2012): The financial cycle and macroeconomics: What have we learnt? BIS Working Papers, 395. http://www.bis.org/publ/work395.pdf (Letöltés: 2017. október 15.)

Brandt, L., Rawski, T. G. (2008): China's great economic transformation. In: Brandt, L., Rawski, T. G. (eds.): China's great economic transformation. Cambridge University Press, New York, 1-26.

Bródy A. (1969): Cycles and equilibrium. European Economic Review, 2., 307-313. http://doi.org/c4gqx5

Chang, C., Chen, K., Waggoner, D. F., Zha, T. (2015): Trends and cycles in China's macroeconomy. NBER Working Paper, 21244. http://www.nber.org/papers/w21244 (Letöltés: 2017. június 2.)

Chavance, B. (ed.) (1987): Régulation cycles et crises dans les économies socialistes. Éditions de l'École des Hautes Études en Sciences Sociales, Paris

Csanádi M. (1995): Honnan tovább? A pártállam és az átalakulás. T-Twins, MTA KTI, Budapest

Csanádi M. (1997): Party-states and their legacies in post-communist transformation. Edward Elgar, Cheltenham 
Csanádi, M. (2006): Self-consuming evolutions. A model on the structure, self-reproduction, self-destruction and transformation of party-states, tested on the Romanian, Hungarian and Chinese cases. Akadémiai Kiadó, Budapest

Csanádi M. (2014): Állami beavatkozás, lokális eladósodás, túlfütöttség és ezek rendszerbeli okai a globális válság alatt Kínában. Tér és Társadalom, 1., 113-129.

Csanádi, M. (2016a): Varieties of communist system transformation and their common systemic grounds: A comparative study of China and East European countries. Journal of Chinese Economic and Business Studies, 4., 385-412. http://doi.org/cjxv

Csanádi, M. (2016b): China in between varieties of capitalism and communism. KTI/IE Discussion Papers, MT-DP 2016/4. http://econ.core.hu/file/download/mtdp/MTDP1604.pdf (Letöltés: 2017. október 24.)

Csanádi, M., Lai, H. (2003): Transformation of the Chinese party-state on national, prefecture and county levels. KTI/IE Discussion Papers, MT-DP - 2003/11. http://www.mtakti.hu/doc/dp/dp/mtdp0311.pdf (Letöltés: 2017. június 16.)

Csanádi M., Lai, H., Gyuris F. (2009): A világválság és hatása a rendszer átalakulására Kínában. Közgazdasági Szemle, 9., 814-834.

CSY (1996-2016): Chinese Statistical Yearbook. A Kínai Statisztikai Hivatal (National Bureau of Statistics of China) évkönyvei. http://www.stats.gov.cn/english/Statisticaldata/AnnualData/ (Letöltés: 2017. június 10.)

Frolic, B. M. (1976): Noncomparative communism: Chinese and Soviet urbanization. In: Field, M. G. (ed.): Social consequences of modernization in communist societies. Johns Hopkins University Press, Baltimore, London, 149-161.

Goldmann, J. (1965): Short and long term variations in the growth rate and the model of functioning of a socialist economy. Czechoslovak Economic Papers, 5., 34-46.

Goodman, D. S. (2004): The campaign to "Open up the West": National, provincial level and local perspectives. The China Quarterly, 178., 317-334. http://doi.org/btpxks

Gyuris, F. (2014): The political discourse of spatial disparities. Geographical inequalities between science and propaganda. Springer, Cham http://doi.org/cjxw

Gyuris F. (2015): Területi egyenlőtlenségek és a beruházások földrajzi eloszlása az átmenet Kínájában. In: Salát G. (szerk.): Kínai álom - kínai valóság. Typotex, Budapest, 42-64.

Ickes, B. W. (1986): Cyclical fluctuations in centrally planned economies: A critique of the literature. Soviet Studies, 1., 36-52. http://doi.org/fbvqv7

Imai, H. (1994): China's endogenous investment cycle. Journal of Comparative Economics, 2., 188-216. http://doi.org/cjrbss

Imai, H. (1996): Explaining China's business cycles. The Developing Economies, 2., 154-185. http://doi.org/c9b4s5

Jordán Gy. (2009): A kínai statisztika megbízhatóságáról. Statisztikai Szemle, 1., 63-82.

Kornai, J. (1981): Some properties of the Eastern European growth pattern. World Development, 9-10., 965-970. http://doi.org/c4b768

Kornai J. (1983): Bürokratikus és piaci koordináció. Közgazdasági Szemle, 9., 1025-1038.

Kornai J. (1993): A szocialista rendszer. Kritikai politikai gazdaságtan. HVG Kiadó, Budapest

Kornai J. (1999): A rendszerparadigma. Közgazdasági Szemle, 7-8., 585-599.

Kornai J. (2016): Még egyszer a „rendszerparadigmáról”: Tisztázás és kiegészítések a posztszocialista régió tapasztalatainak fényében. Közgazdasági Szemle, 10., 1074-1119. http://doi.org/cjxz

Liu, Z., Spiegel, M. M. (2017): Reserve requirements as a Chinese macro policy tool. Federal Reserve Bank of San Francisco, FRBSF Economic Letter, 2017-15. http://www.frbsf.org/economicresearch/publications/economic-letter/2017/may/reserve-requirements-as-chinese-macro-policytool/ (Letöltés: 2017. június 2.)

Meng, G. (2003): The theory and practice of free economic zones: A case study of Tianjin, People's Republic of China. Peter Lang, Frankfurt am Main

Meusburger, P. (1997): Spatial and social inequality in communist countries and in the first period of the transformation process to a market economy: the example of Hungary. Geographical Review of Japan (Ser. B), 70., 126-143.

Mihályi, P. (1992): Socialist investment cycles: Analysis in retrospect. Kluwer, Dordrecht http://doi.org/brbw6h 
Nagy T. (1954): A népgazdaság tervszerü (arányos) fejlődésének törvénye. Magyar-Szovjet Közgazdasági Szemle, 3., 201-225.

Naughton, B. (1987): Macroeconomic policy and response in the Chinese economy: The impact of the reform process. Comparative Economics, 3., 334-353. http://doi.org/bbp9cx

NBSC (é.n.) Statistical Database. A Kínai Statisztikai Hivatal (National Bureau of Statistics of China) online adatbázisa. http://data.stats.gov.cn/english/. (Letöltés: 2017. június 10.)

Nemes Nagy J. (1987): Regionális folyamatok a nyolcvanas évek első felében. Országos Tervhivatal, Tervgazdasági Intézet, Budapest (Tervgazdasági Közlemények; 18.)

Nemeskéri Zs. (2003): A régiók fejlődése és konvergenciája Kínában. PTE Felnőttképzési és Emberi Erőforrás Fejlesztési Intézet, Pécs

Oppers, S. E. (1997): Macroeconomic cycles in China. Working Paper of the International Monetary Fund, WP/97/135. https://www.imf.org/external/pubs/ft/wp/wp97135.pdf (Letöltés: 2017. június 2.)

Soós, K. A. (1975): Causes of investment fluctuations in the Hungarian economy. Eastern European Economics, 2., 25-36. http://doi.org/cjx2

Soós K. A. (1986): Terv, kampány, pénz. Közgazdasági és Jogi Könyvkiadó, Budapest

Soós, K. A. (1987): Informal pressures, mobilization, and campaigns in the management of centrally planned economies. Economics of Planning, 1., 39-48.

Soós, K. A. (1989): Regular investment cycles or irregular investment fluctuations under central planning? In: Frateschi, C. (ed.): Fluctuations and cycles in socialist economies. Avebury, Aldershot, 61-83.

Szelényi I. (1990): Városi társadalmi egyenlőtlenségek: tanulmányok. Akadémiai Kiadó, Budapest

Sztálin, J. V. (1953): A szocializmus közgazdasági problémái a Szovjetunióban. Szikra, Budapest

Vági G. (1982): Versengés a fejlesztési forrásokért. Közgazdasági és Jogi Könyvkiadó, Budapest

Wiles, P. (1982): Are there any communist economic cycles? The ACES Bulletin, 2., 1-20.

Wong, C. (2011): The fiscal stimulus programme and public governance issues in China. OECD Journal on Budgeting, 3., 1-21. http://doi.org/dkf824

Yuan, Y. (2015): Looking back 14 years after accession: Case of China. Felszólalás a Third China Round Table on WTO Accessions c. rendezvényen Dusanbéban (Tádzsikisztán), 2015. június 2. https://www.wto.org/english/thewto_e/acc_e/Session2YuanYuanPostAccessionLookingback14 yearafter.pdf (Letöltés: 2017. június 19.)

Zou, H. (1991): Socialist economic growth and political investment cycles. World Bank Working Paper Series, WPS 615. http://documents.worldbank.org/curated/en/530501468774869575/pdf/ multiopage.pdf (Letöltés: 2017. június 2.)

Zou, H. (1993): A note on the Bauer-Kornai investment cycle theory. China Economic Review, 1., 75-81. http://doi.org/c628fm 